\section{ECONOMICS}

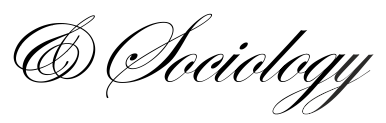

Urbancová, H., Hudáková, H. (2017). Benefits of Employer Brand and the Supporting Trends. Economics and Sociology, 10(4), 41-50. doi:10.14254/2071789X.2017/10-4/4

\title{
BENEFITS OF EMPLOYER BRAND AND THE SUPPORTING TRENDS
}

\author{
Hana Urbancová, \\ University of Economics and \\ Management, \\ Prague, Czech Republic, \\ E-mail: hana.urbancova@vsem.cz.
}

Monika Hudáková, School of Economics and Management in Public Administration, Bratislava, Slovak Republic, E-mail: monika.hudakova@vsemvs.sk.

Received: March, 2017

1st Revision: July, 2017

Accepted: October, 2017

DOI: $10.14254 / 2071-$

789X.2017/10-4/4

JEL Classification: M12, M14, M54

\begin{abstract}
Shortage of qualified staff and constant struggle for talents along with the retention of most valuable employees belong to the hottest personnel issues for the majority of organizations nowadays. HR marketing can significantly help in these areas. Within HR marketing human resources officers become those marketers who strive to keep their organization's name in the minds of all stakeholders, thus drawing their attention to organization's qualities as an employer, and in such a way winning by taking care of the most talented employees. The aim of this paper is to determine and evaluate the benefits resulting from employer branding and also to identify the trends conducive to the strengthening of an employer's brand. The data were obtained using a questionnaire survey $(n=492)$ in the selected Czech organizations. The results show that employer branding is an important element in all economic sectors and businesses can build their brands by focusing primarily on the stability of their current employees, their continuous development and their retaining of the most valuable knowledge. The article focuses on new strategic trends in building employer's good brand and attracting the most knowledgable workers.
\end{abstract}

Keywords: employer brand; HR marketing; employees; organization; Czech Republic; employees' retention.

\section{Introduction}

Well-adjusted HR marketing is currently a trend that affects not only management of the internal environment of an organization, but also impacting on its external environment. Not only a logo, history, quality of products and services etc., but also employees are the most important ambassadors of an employer's brand (Edwards and Edwards, 2013). Since most of employees act externally, they speak - directly or indirectly - about the organization in which they are working: they may recommend company's products and services to their friends and familty, they present their company as a suitable employer to others etc. These are the primary facts the employer should be interested in when there is the lack of talented employees with sufficient competencies (Elving et al., 2012). Minchington (2016) states that every organization may be involved in HR marketing at five levels, where the first one includes discussion with one person only, most commonly an HR department representative, responsible for addressing these issues. On the contrary, the fifth level is when all managers have been trained in employer branding and are aware of the fact that any step in their decision-making has a great impact on HR marketing. Working with employer's brand and developing an appropriate HR marketing strategy must, according to (Minchington, 2016), 
include a business strategy that places a comprehensive emphasis on three pillars: namely, customers, employees and financial performance of the organization. Organizations that prefer only one of the three parts are not sustainable in a long term (Minchington, 2016; Grabara, 2013). However, it is necessary to realize that if HR marketing is to help build a good employer brand, it must work only with true information with which current employees as well as potential ones can go along with (Grabara, 2013).

It can be concluded from the research that employer's brand has to pay attention to the need to share organization's core values so that to be perceived as an attractive employer, to create space for developing talents of the current employees, to promote innovation, and to build pride among staff for the products and services provided by this organization (Helm, 2011; Saini et al., 2014). Branding from the marketing point of view is used very often according to (Neumeier, 2006) or (Keller, 2007), however, the term "employer branding" is relatively new. Aaker (2003) states that most of the staff seeking work will give preference to a renowned employer instead of an unknown organization. Just a good employer brand strengthens the positive view of stability, prosperity and the good name of the subject in the eyes of potential candidates as (Minchington, 2016) states. Employer branding is a complex process which must impact all the existing and potential stakeholders as confirmed by (Bursová, 2009) and (Van Mossevelde, 2014). Focus on employer branding in the field of motivation and activation of employees matters and in search for new potential candidates for various work positions in organizations the employer branding increases the number of candidates for one position (Hučková, 2012; Bursová, 2009; Minchington, 2016). Wilden et al. (2010) also support the previous statement, adding that employer branding is a set of psychological, economic and functional benefits, which connect potential employees with their employers. The knowledge of these benefits in every organization helps businesses create an attractive and competitive employer brand, increase knowledge-sharing between generations of employees and increase competitive advantage as confirmed by the results of Van Mossevelde (2014), Wilden et al. (2010) or Urbancová et al. (2017). Therefore, the focus should be on possibilities and the ways how to stimulate employer branding nowadays and in the near future.

The aim of this paper is therefore to determine and evaluate the benefits resulting from employer branding and also to identify trends conducive to strengthening of such a brand. The partial aims are to find out whether there is a statistical dependence between the selected qualitative characteristics and to propose measures to address these issues in the observed organizations.

The first chapter focuses on theoretical background; the second chapter treats the methodological procedures used to obtain the results. The third chapter discusses these results and also propose measures to be taken. The final section of the paper includes recommendations, also indicating the limits and benefits of the current study, thus pointing at directions for further research.

\section{Literature review}

An attractive employer brand is according to Pop (2008) a combination of the tangible and intangible factors such as the package of employee benefits, the culture and work environment, the management involvement, the image and reputation of the brand which is confirmed by Helm (2011). Therefore an essential part of every contemporary organization is its HR department, or more precisely performed HR activities. The emphasis placed on them has been increasing from year to year, required performance, success and achievement of set goals (Jenkins, 2009; Saxena, Jain, 2012). For this reason, the importance of a relatively new discipline, namely HR marketing, has been increasing (Martin et al., 2011; Ng et al., 2010). 
In connection with the aforementioned, the fundamental task of HR marketing can be formulated, it means to ensure and promote developing a company's good reputation thanks to which the organization can differentiate from its competitors and thus to increase its attractiveness as an employer.

On the one hand, HR marketing focuses on current employees to motivate and retain them in the organization (Hitka et al., 2015; Love and Singh, 2011). On the other hand, its objects of interest are potential employees, when it is necessary to target and approach a particular group in an appropriate manner and then to win them for the organization (Archana et al., 2014; Woźniak, 2015). Thanks to the war for talents, which is currently taking place, the organization's approach and its attractiveness are crucial (Hershatter and Epstein, 2010). As a matter of fact, employees do not want to identify themselves only with the job, but also with their employer.

Nevertheless, effective HR marketing includes much more than just the ability to make the employer more attractive and to create a pleasant working environment (HR Forum, 2016). Ideally, the strategy of HR marketing should be incorporated and respected in all other activities of human resources management. HR marketing is not only one of the elements of human resources policy, nor only a tool of the HR department. It is a basis for building relationships with employees, these relationships being based on a particular system, investment and mutual approval and consent (Aggerholm et al., 2011).

However, it is necessary to point out that despite the growing importance of human capital, not all organizations realize the importance of internal HR marketing and they still focus only on external activities (Kazdová, 2014). Particularly current employees are ambassadors and propagators of the employer brand who subsequently spread either positive or negative "word-of-mouth" about their organization. It is therefore important how the organization takes care of its employees, what working conditions it creates and what employee benefits are available to staff (Woźniak, 2015). Aaker (2003) states that is important to monitor the factors that currently form employer branding of the organisation.

HR marketing can be understood as the use of marketing approach in the field of human resources. Basic differences between HR marketing and classic marketing consist in, for example, the subject or object of interest, in market entities, a target market or the aim of the given marketing type. However, HR marketing is closely linked with concepts such as employer's reputation, or employer's brand, labour market, human capital and overall business strategy. The benefits of HR marketing include an increase in company's competitiveness and employees' engagement, decrease in financial and time demands of the recruitment process, strengthening the employer brand, etc. ( $\mathrm{Ng}$ et al., 2010, Saini et al., 2014). The marketing elements used in human resources management can include for example a marketing process, basic course of which can also be applied to the human resources area. In addition to the marketing process, the S-T-P method may also be mentioned, i.e. segmentation, targeting and positioning; in this case, however, each of these steps applies to potential employees. Likewise, the 4Ps (product, price, place, and promotion) or its extended modification of 6Ps are used. Also the customer relationship cycle can be taken over from marketing and adapted for employees (HR Forum, 2016; Martin et al., 2011).

The effects of HR marketing can be measured by a number of quantitative indicators (economic and socio-economic variables) and qualitative indicators, which relate to the behaviour of employees themselves. The essential HR marketing tool is also HR survey that aims to collect and evaluate all relevant information. Such information may come both from the external and internal environments of the organization.

It can be summarized that recognizing the needs and wishes of both current and potential employees is one of the key strategic challenges, because by their identification and 
subsequent satisfaction the organization can build a good employer brand and achieve a considerable competitive advantage and competitiveness in the labour market.

\section{Methodological approach}

Relevant scientific monographs and scientific articles in the Web of Knowledge and Web of Science dealing with the current issues, namely employer branding and HR marketing, were analysed within the secondary sources (see the list of references).

Primary data was obtained by an anonymous electronic survey targeted at Czech organizations. To obtain data, a quantitative type of survey was conducted using the questionnaire technique of data collection. The organizations were selected only for the given research and their composition is random, it does not respect the exact division ratio in the national economy. The questionnaire respected the ethical aspect and anonymity of respondents.

A total of 1041 randomly selected companies took part in the survey. They were contacted by e-mail and the response rate was $47.36 \%(n=492)$. The questionnaire survey was completed by persons responsible for human resources in an organization, mostly by CEO or human resources department director. For potentially ambiguous questions, terms were explicitly defined.

The structure of organizations participating in the survey was as follows:

- Business sector: primary $3.3 \%$, secondary $16.5 \%$ and tertiary $80.2 \%$.

- Majority ownership: Czech $74.2 \%$ and foreign $25.8 \%$.

- Organization size: <50 employees $40.4 \%$, from 51 to 249 employees $27.4 \%$, 250 employees and more $32.2 \%$.

- The ratio of men and women employed in the organization: more women than men $36.4 \%$, the same ratio (50:50) $18.9 \%$, and more men $44.7 \%$.

Closed or semi-open questions, which were compiled on the basis of the study of literature, documents and other related research, were used to obtain answers (Anderson, 2012; Hebák et al., 2004). In order to evaluate the results, descriptive statistics tools such as absolute and relative frequencies, dependence tests ( $\chi 2$ test) and tests of strength dependence (Cramer's V) were used. If the p-value was lower than $\alpha=0.05$, the null hypothesis was rejected.

Within the multivariate statistical methods, the factor analysis was used to establish factors that summarize behaviour of respondents (managers) into meaningful groups. Before using the factor analysis a correlation matrix was created and then it was further analysed for suitability of further calculations using multivariate methods. At first the correlation analysis, then the principal components analysis and subsequently the factor analysis using Varimax were used for calculations. The Kaiser Guttman rule (i.e. essential factors have a variance value greater than 1) was used to select the essential factors. As significant values were regarded those whose value exceeded 0.3 (Anderson, 2009).

According to Anderson (2009), the factor analysis was used only as verification. The emphasis of commenting on the factor analysis results is laid on the meaningfulness and substantiation of factors in terms of theory and practice in human resource management. In case of human resources research, this method is often used by researchers and provable in work with people (Anderson, 2009). Just because of the fact that factor analysis is often used in the human resources area, it was also used to prepare this article. To evaluate the data, the SPSS 23 statistical software and MS Excel 2010 were used. 


\section{Conducting research and results}

The first part of the chapter presents the results of the research in organizations focused on benefits from employer branding and its supporting trends. The research results have identified 5 major benefits resulting from employer branding, the pivotal role being played by employees themselves. It can be summarized that size, gender structure and ownership of the organizations can influence the benefits resulting from employer branding. The detailed results including the testing of statistical dependencies are shown in Table 1.

Table 1. Benefits resulting from employer branding

\begin{tabular}{|c|c|c|c|c|c|c|}
\hline Benefits & $\begin{array}{l}\text { Absolute } \\
\text { frequencies }\end{array}$ & $\begin{array}{c}\text { Relative } \\
\text { frequencies }\end{array}$ & $\begin{array}{c}\text { Sector } \\
\text { p-value } \\
\text { (Cramer's V) }\end{array}$ & $\begin{array}{c}\text { Size } \\
\text { p-value } \\
(\text { Cramer's V) }\end{array}$ & $\begin{array}{c}\text { Gender } \\
\text { structure } \\
\text { p-value } \\
\text { (Cramer's V) }\end{array}$ & $\begin{array}{l}\text { Ownership } \\
\text { p-value } \\
\text { (Cramer's V) }\end{array}$ \\
\hline $\begin{array}{l}\text { Winning new } \\
\text { talented } \\
\text { employees }\end{array}$ & 344 & 22.4 & 0.479 & $\begin{array}{c}0.014 \\
(0.132, \text { low })\end{array}$ & 0.904 & 0.065 \\
\hline $\begin{array}{l}\text { Retaining key } \\
\text { employees }\end{array}$ & 368 & 23.9 & 0.630 & 0.235 & $\begin{array}{c}0.047 \\
(0.112, \text { low }) \\
\end{array}$ & 0.154 \\
\hline $\begin{array}{l}\text { Increasing } \\
\text { motivation of } \\
\text { current employees }\end{array}$ & 310 & 20.1 & 0.247 & $\begin{array}{c}0.041 \\
(0.114, \text { low })\end{array}$ & $\begin{array}{c}0.008 \\
(0.112, \text { low })\end{array}$ & 0.154 \\
\hline $\begin{array}{l}\text { Improving public } \\
\text { brand awareness } \\
\text { of the organization }\end{array}$ & 291 & 18.9 & 0.441 & 0.257 & 0.283 & $\begin{array}{c}0.013 \\
(0.112, \text { low })\end{array}$ \\
\hline $\begin{array}{l}\text { Improving } \\
\text { financial } \\
\text { performance }\end{array}$ & 215 & 14.0 & 0.345 & 0.067 & 0.860 & 0.918 \\
\hline Others & 11 & 0.7 & $\mathrm{x}$ & $\mathrm{x}$ & $\mathrm{x}$ & $\mathrm{x}$ \\
\hline
\end{tabular}

Source: own compilation.

Furthermore, 5 major trends that help build a good employer's brand in the eyes of both current and potential employees have been identified. The detailed results including the testing of statistical dependencies are presented in Table 2. The results confirmed that the size and ownership are important for supporting employer branding.

Table 2. Trends supporting employer branding

\begin{tabular}{lcccccc}
\hline Trends & $\begin{array}{c}\text { Absolute } \\
\text { frequencies }\end{array}$ & $\begin{array}{c}\text { Relative } \\
\text { frequencies }\end{array}$ & $\begin{array}{c}\text { Sector } \\
\text { p-value } \\
\text { (Cramer's V) }\end{array}$ & $\begin{array}{c}\text { Size } \\
\text { p-value } \\
\text { (Cramer's V) }\end{array}$ & $\begin{array}{c}\text { Gender } \\
\text { structure } \\
\text { p-value } \\
\text { (Cramer's V) }\end{array}$ & $\begin{array}{c}\text { Ownership } \\
\text { p-value } \\
\text { (Cramer's V) }\end{array}$ \\
\hline $\begin{array}{l}\text { Knowledge } \\
\text { continuity }\end{array}$ & 2 & 3 & 4 & 5 & 6 & 7 \\
\hline $\begin{array}{l}\text { Talent } \\
\text { Management }\end{array}$ & 366 & 28.6 & 0.653 & 0.150 & 0.611 & 0.981 \\
\hline Age Management & 130 & 10.5 & 0.501 & $\begin{array}{c}0.000 \\
(0.181, \text { low })\end{array}$ & 0.144 & $\begin{array}{c}0.000 \\
(0.173, \text { low })\end{array}$ \\
\hline $\begin{array}{l}\text { Diversity } \\
\text { Management }\end{array}$ & 175 & 14.1 & 0.425 & $\begin{array}{c}0.000 \\
(0.180, \text { low })\end{array}$ & 0.171 & $\begin{array}{c}0.000 \\
(0.173, \text { low })\end{array}$ \\
\hline
\end{tabular}




\begin{tabular}{lcccccc}
\hline \multicolumn{1}{c}{1} & 2 & 3 & 4 & 5 & 6 & 7 \\
\hline $\begin{array}{l}\text { Career } \\
\text { Management }\end{array}$ & 212 & 17.1 & 0.296 & $\begin{array}{c}0.000 \\
(0.270, \\
\text { moderate })\end{array}$ & 0.933 & $0.000(0.162)$ \\
\hline $\begin{array}{l}\text { Others strategic } \\
\text { trends }\end{array}$ & 9 & 0.7 & $\mathrm{x}$ & $\mathrm{x}$ & $\mathrm{x}$ & $\mathrm{x}$ \\
\hline
\end{tabular}

Source: own compilation.

The results (identified benefits and trends) were then tested by the factor analysis which had a verification character. The calculated values in the factor analysis indicate the extent to which the newly created variable correlates with the original variables. Based on the evaluation of calculated data, 3 important factors meeting the criteria laid down by the methodology have been identified. Table 3 shows the significance of individual benefits resulting from employer branding on the basis of percentages and their sum total.

Table 3. Variance explained by factors

\begin{tabular}{cccc}
\hline Factor & Total Variance & Total \% of Variance & Cumulative \% of Variance \\
\hline 1 & 1.852 & 30.874 & 30.874 \\
\hline 2 & 1.084 & 18.063 & 48.937 \\
\hline 3 & 1.008 & 16.798 & 65.735 \\
\hline
\end{tabular}

Source: own compilation.

The factor 1 variance can be considered to be the most significant (30.874). The 3 mentioned factors explain $65.735 \%$ of the sample behaviour or the possibilities of resulting characteristics. The factor analysis results are shown in Table 4.

Table 4. Resultant factors by the Varimax method

\begin{tabular}{lccc}
\hline \multicolumn{1}{c}{ Variable } & Factor 1 & Factor 2 & Factor 3 \\
\hline Winning new talented employees & 0.697 & 0.185 & -0.108 \\
\hline Retaining key employees & 0.756 & 0.054 & 0.051 \\
\hline Increasing motivation of current employees & 0.729 & 0.003 & 0.119 \\
\hline $\begin{array}{l}\text { Improving public brand awareness of the } \\
\text { organization }\end{array}$ & -0.014 & 0.865 & -0.149 \\
\hline Improving financial performance & 0.230 & 0.692 & 0.264 \\
\hline Others & 0.024 & 0.032 & 0.958 \\
\hline Total \% of Variance & 30.874 & 18.063 & 16.798 \\
\hline Name of factor & $\begin{array}{c}\text { Pillar of } \\
\text { employees }\end{array}$ & $\begin{array}{c}\text { Pillar of Customers } \\
\text { and Profit }\end{array}$ & $\begin{array}{c}\text { Other } \\
\text { factors }\end{array}$ \\
\hline
\end{tabular}

Source: own compilation.

The first factor, in the first place, highlights the pillar of employees. Such organizations emphasize ways of attracting and winning new talented employees (0.697), retaining current key employees (0.756) and increasing their motivation (0.729), which strongly facilitates employer branding. The first factor can be called the "Pillar of Employees". The coefficients of found factors range from 0.697 to 0.756 (a high quality of found coefficients). 
The second factor includes communication with the public and improving the financial situation by promoting the quality of company's products, services, and the employer as the top-quality one (0.865 - high quality of coefficient, 0.692 - higher quality); therefore it is called the "Pillar of Customers and Profit". The third factor includes other variables that indirectly result from HR marketing, such as improving the team spirit, increasing employee loyalty etc. Table 5 presents the significance of individual trends in employer branding.

Table 5. Variance explained by factors

\begin{tabular}{cccc}
\hline Factor & Total Variance & Total \% of Variance & Cumulative \% of Variance \\
\hline 1 & 1.838 & 30.626 & 30.626 \\
\hline 2 & 1.160 & 19.332 & 49.957 \\
\hline 3 & 1.002 & 16.695 & 66.652 \\
\hline
\end{tabular}

Source: own compilation.

We can be summarized, that the factor 1 variance can be considered to be the most significant (30.626). The 3 mentioned factors explain $66.652 \%$ of the sample behaviour (Table 6 shows the factor analysis results).

Table 6. Resultant factors by the Varimax method

\begin{tabular}{lccc}
\hline \multicolumn{1}{c}{ Variable } & Factor 1 & Factor 2 & Factor 3 \\
\hline Knowledge continuity & 0.107 & 0.141 & 0.723 \\
\hline Talent Management & -0.044 & 0.808 & 0.296 \\
\hline Age Management & 0.861 & 0.118 & 0.045 \\
\hline Diversity Management & 0.863 & 0.064 & 0.074 \\
\hline $\begin{array}{l}\text { Career } \\
\text { Management }\end{array}$ & 0.273 & 0.747 & -0.209 \\
\hline Others strategic trends & -0.002 & 0.062 & -0.713 \\
\hline Total \% of Variance & $\begin{array}{c}30.626 \\
\text { Stability of } \\
\text { employees }\end{array}$ & $\begin{array}{c}19.332 \\
\text { Employee } \\
\text { development }\end{array}$ & $\begin{array}{c}\text { Retention of key } \\
\text { knowledge }\end{array}$ \\
\hline
\end{tabular}

Source: own compilation.

The first of the found factors (stability of employees) emphasizes the fact that it is necessary to present the organization outwards as non-discriminatory (by age, gender, nationality etc.) and to create diverse teams. The second of the found factors highlights development of employees, namely both current and new, and an emphasis is placed on continuous learning and developing career plans for individuals in cooperation with the HR department. The third factor highlights retention of key knowledge of employees even if personnel changes (retirements, etc.), and choosing suitable successors to those retiring from talented employees. Also other trends, or more precisely situations, indirectly influence the continuity of knowledge transfer, e.g. willingness to share knowledge, willingness to transfer knowledge, etc. The found coefficients range from 0.723 to 0.863 , which indicates a high quality of coefficients. Based on the foregoing it can be concluded that HR marketing aims to actively work with employees in order to avoid their turnover, to retain key employees and teams and to ensure the performance stability of workforce and the entire organization. 


\section{Discussion}

It is necessary to realize that a strong brand thanks to appropriately defined HR marketing is what protects the organization from its competitors and creates a competitive advantage. It is also necessary to realize that the good employer brand across all sectors and in all organizations which is confirmed by Urbancová et al. (2017), Aaker (2003). The employer branding has the benefits (Minchington, 2016; Wilden et al., 2010), which was confirmed by this survey results in area of HR activities (pillar of employees and pillar of customers and profit).

However, it is imperative that the HR department representatives cooperate with marketing specialists who can contribute by their experience to influence customers in HR marketing and to retain current employees and to win new top talents, which has been confirmed by the research of Chand (2015). If employees perceive their employer's brand as a good one, it can be assumed that this fact will influence also other surrounding employees in the labour market. Organizations' representatives increasingly participate in job fairs, visit universities and higher education institutions; cooperate with the academic world and offer internships and placement programmes to students already during their studies. It was confirmed, that it is very important to focus on winning new talented employees and increasing motivation of current employees, it is accordance with Hučková (2012).

HR marketing is successful when employees themselves are involved in their company's presentations and recruitment campaigns, which is in line with the conclusions of Edwards and Edwards (2013), Elving et al. (2012) or Grabar (2013). However, in order to develop and set HR marketing, it is necessary to continuously analyse changes in both internal and external environments of the organization, as is underlined by the research of Aggerholm et al. (2011). Employer branding must be based on trends and changes both inside and outside the organization and, last but not least, be credible, comprehensible and truly promoted by the employees themselves. Based on the research of Jenkins (2009), Love and Singh (2011), and Saxena and Jain (2012) employer branding using a suitably chosen HR marketing can currently be regarded as a significant tool for strategic management of human resources. It can be summarized that the results show that the employer branding can be stimulated by strategic trends in the HR which is confirmed by Van Mossevelde (2014). It can be inferred that employer branding is an important element in all sectors of economy, be it primary, secondary or tertiary. On the contrary, both benefits and applied trends are influenced by the number of employees in the organization and it is accordance with Urbancová et al. (2017). It is very important to focus on stability of employees and retention of key knowledge. The organizations must not forget the integration of HR marketing strategy into the overall strategy of the organization and focus on employee development and emphasis on content marketing. Thus candidates will be provided with truly relevant information about the organization, which will also serve for building and strengthening the employer's brand.

\section{Conclusion}

The results show that good employer branding creates a competitive advantage which is important in every organizations nowadays. The results confirmed that employer branding has the benefits in good HR process (0.697 to 0.756), process of public brand to the customers and good employer and create a profit (0.692 to 0.865$)$.

It is necessary to realize that the more employees the organization has, the more it must seek to stabilize and satisfy them so that they become part of the organization itself and identify themselves with its goals and values. Retaining current employees may be regarded 
as the main benefit of employer branding. The application of talent management is the trend that currently helps it. 3 factors influencing successful employer branding have been identified, namely stability of employees (0.861 to 0.863$)$, development of employees (0.747 to 0.808$)$ and retention of key knowledge (0.723).

The practical contribution of the paper is to present results of the conducted research and to identify major factors influencing successful employer branding. In view of the fact that this is a topical issue, it would be appropriate in future research to determine efficiency of individual ways for winning new top talents in the labour market with respect to the application of HR marketing.

\section{Acknowledgement}

This contribution is a follow-up to the project of University of Economics and Management, grant number GCES0415.

\section{References}

Aggerholm, H. K., Andersen, S. E., Thomsen, C. (2011). Conceptualising employer branding in sustainable organisations, Corporate Communications. An International Journal, 16(2), 105-123.

Anderson, V. (2009). Research Method in Human Resource Management. 2 ed. London: Chartered Institute of Personnel Development.

Archana, L., Nivya, V. G., Thankam, S. M. (2014). Recruitment through social media area: Human Resource. Journal of Business and Management, 1, 37-41.

Bursová, I. (2009). Ma smysl v teto době budovat zaměstnavatelskou značku? A jak na to? Available at http://www.hrmanager.cz/files/hrforum0309.pdf (accessed May 2015).

Edwards, M. R., Edwards, T. (2013). Employee responses to changing aspects of the employer brand following a multinational acquisition: a longitudinal study. Human Resource Management, 52(1), 27-54.

Elving, W. J. L, Westhoff, J. J. C., Meeusen, K., Schoonderbeek, J. W. (2012). The war for talent? The relevance of employer branding in job advertisements for becoming an employer of choice. Journal of Brand Management, 20(5), 355-373.

Grabara, J. (2013). Employer's expectations towards the employees from the marketing and management department. Polish Journal of Management Studies, 7, 58-70.

Hebák, P., Hustopecký, J., Jarošová, E., Pecáková, I. (2004). Statistics and data processing (in Czech). Prague: Informátorium.

Helm, S. (2011). Employees' awareness of their impact on corporate reputation. Journal of Business Research, 64(7), 657-663.

Hershatter, A., Epstein, M. (2010). Millennials and the World of Work: An Organization and Management Perspective. Journal of Business and Psychology, 25(2), 211-223.

Hitka, M., Stachová, K., Balážová, Ž., Stacho Z. (2015). Differences in Employee Motivation at Slovak Primary Schools in Rural and Urban Areas. International Education Studies, $8(5), 33-42$.

Hučková, K. (2012). Jak vybudovat autentickou značku zaměstnavatele? Available at http://www.personalni--marketing.cz/detail-clanku/jak-vybudovat-autentickou--znackuzamestnavatele (accessed May 2015).

HR Forum (2016). People Management Forum, 5, 10.

Chand, S. (2015). Personnel Research: Definition and Purpose of Personal Research. YourArticleLibrary.com: The Next Generation Library [online]. 2015 [cit. 2016-05-22]. 
Available at: www.yourarticlelibrary.com/employee-management/personnel-researchdefinition-and-purpose-of-personal-research/35507/.

Jenkins, A. K. (2009). Keeping the talent: understanding the needs of engineering and scientists in the defense acquisition workforce. Defense Acquisition Review Journal, 1, 164-170.

Keller, K. L. (2007). Strategické ř́zení značky. 1.vyd. Praha: Grada Publishing.

Kazdová, A. (2014). Even candidates build your brand (in Czech). Modern Management, 49(10), 61-63.

Love, L. F., Singh, P. (2011). Workplace Branding: Leveraging Human Resources Management Practices for Competitive Advantage Through "Best Employer Surveys". Journal of Business and Psychology, 26(2), 175-181.

Martin, G., Gollan, P. J., Grigg, K. (2011). Is there a bigger and better future for employer branding? Facing up to innovation, corporate reputations and wicked problems in SHRM. International Journal of Human Resource Management, 22(17), 3618-3637.

Minchington, B. (2016). People Management Forum, 5, 10.

Neumeier, M. (2006). The Brand Gap. 2. vyd. Berkeley: New riders.

Ng, E. S. W., Schweitzer, L., Lyons, S. T. (2010). New generation, great expectations: A field study of the millennial generation. Journal of Business and Psychology, 25(2), 281-292.

Saini, G. K., Rai, P., Chaudhary, M. K. (2014). What do best employer surveys reveal about employer branding and intention to apply? Journal of Brand Management, 21(2), 95111.

Saxena, P., Jain, R. (2012). Managing career aspirations of generation Y at work place. International Journal of Advanced Research in Computer Science and Software Engineering, 2(7), 114-118.

Urbancová, H., Richter, P., Kučírková, L., Jarkovská, M. (2017). Employer Branding in Agriculture Sector: Making a Company Attractive for Potential Employees. Agricultural Economics, 63, 217-227.

Van Mossevelde Ch. (2014). What is Employer Branding? Available at http://universumglobal.com/2014/03/whatis-employer-branding/ (accessed May 2015).

Wilden, R., Gudergan, S., Lings, I. (2010). Employer branding: Strategic implications for staff recruitment. Journal of Marketing Management, 26, 56-73.

Woźniak, J. (2015). The Use of Gamification at Different Levels of E-Recruitment. Management Dynamics in the Knowledge Economy, 3(2), 257-278. 